\title{
ORIGENS DA PEDOLOGIA DO BRASIL: RESENHA HISTÓRICA
}

\author{
Carlos Ernesto G. R. Schaefer (*), Antônio Francisco Sá e Melo Marques (**) \\ \& Jackson Cleiton Ferreira Campos(***)
}

\begin{abstract}
This paper presents an outline of the historical background of the Brazilian Pedology, from its infancy, soon after the Portuguese occupation, to the early days of the $20^{\text {th }}$ century, when it emerges as a separate branch of agriculture and earth sciences in Brazil. In order to achieve a broader vista over the Brazilian Pedology, a considerable amount of papers, books, reports and bulletins has been consulted and dealt with, thenceforth a provisional review is presented and discussed. The slow evolution of analytical observations of soils in the field is the overall characteristic of this science as a whole. Some little known naturalists/scientists, like the Brazilian Alexandre Rodrigues Ferreira and the italian Father Antonil, deserve to be considered as prominent beginners of Brazilian pre-Pedology, whilst more traditional naturalists like Agassiz and Hartt have poor contributions to the understanding of pedology. Others, like Saint-Hilaire and Burton, have made detailed descriptions of soils in Brazil, but both lack the necessary basic knowledge to explain many aspects of these soils, in terms of chemical, physical and mineralogical atributes. The indigenous knowledge is also considered, and some examples illutrate the vast empirical view of soils that were entirely lost by their extinction, and can never be traced back. We consider that the Brazilian pedology needs a closer interplay between earth and agriculture scientists, in order to achieve a higher stand and answer the many demands that it now faces.
\end{abstract}

\section{NOTA EXPLICATIVA}

A pedologia é reconhecida como um ramo distinto das geociências, originada do desmembramento de ciências congêneres, tais como geologia e geomorfologia, nos finais do século passado, a partir do reconhecimento do solo como corpo natural (e não mais simplesmente a "terra vegetal" ou o "manto intemperizado da superfície terrestre") e elaboração dos primeiros sistemas taxonômicos ou classificações naturais. É reconhecido de maneira consensual que esta ciência teve o seu início marcado pelos trabalhos do russo Dokuchaev nos finais do século passado, com a primeira classificação de solos apresentada em 1886 e a segunda em 1900, seguindo-se a de Sibirtsev, que apenas modificou o trabalho de Dokuchaev. Só foi possível estabelecer uma classificação natural dos solos após reconhecer-se que estes eram corpos naturais independentes com morfologias distintas, sub-aéreos, com propriedades que refletiam os agentes de formação. Aos pioneiros Russos, seguiram-se os trabalhos de Zakharov, Glinka, Gedroiz, os americanos Hilgard, Whitney, Coffey ${ }^{(1)}$ e posteriormente Marbut ${ }^{(2)}$. Houve, claro, produções científicas anteriores em que o solo era reconhecido como fator de produção vegetal, bem como sistemas classificativos das terras com finalidades utilitárias que passam pelos primórdios das civilizações orientais (Chinesa) e ocidentais (Romana e medieval), os quais não deverão ser incluídos no domínio da pedologia, dada a inexistência desta.

Neste trabalho buscou-se coligir dados históricos sobre conhecimento empírico e técnico-científico relativo aos solos no Brasil, desde os primórdios das geociências, nas datas anteriores à criação da ciência do solo propriamente dita, denominada pedologia. Dentro desse cenário sobre as origens da Pedologia, procurou-se desvendar os traços iniciais de sua evolução em terras brasileiras, por observadores brasileiros ou não, que ao observarem e descreverem a paisagem, verificaram ser o fator solo um dos mais destacados na distribuição das formações vegetais, atividades agrícolas, e até mesmo, das diferentes condições de adaptação humana aos ambientes. Não foi o escopo deste trabalho um levantamento histórico da Pedologia como ciência, à partir do século XX, assunto este tratado em recente trabalho publicado no Boletim da Sociedade Brasileira de Ciência do Solo (Moniz 1997).

\section{INTRODUÇÃO}

O presente trabalho consistiu em pesquisa bibliográfica de autores que, em datas anteriores ao desenvolvimento da pedologia, estudaram o território

(1) Coffey (1912) afirmou "O solo é um corpo natural, independente, uma formação biogeológica, essencialmente distinta da rocha subjacente". Esta ênfase na influência biológica na pedogênese, seria paulatinamente abandonada, em favor de um reducionismo físico-químico.

(2) Curtis Marbut foi influenciado por Coffey, e estudou com William Morris Davis, o pai da geomorfologia moderna, os quais moldaram as idéias de pedologia que ele sintetizaria mais tarde, com grande eloquência, no $1^{\circ}$ Congresso Internacional de Ciência do Solo, em 1927 . De sua visita ao Brasil, e em especial, à Amazônia, ficaram relatos notáveis sobre os solos, muito avançados para a nascente pedologia brasileira de então. 
brasileiro nos seus aspectos físicos e bióticos, ou naturais, compreendendo as características geográficas, botânicas, zoológicas, geológico-minerais e humanas. Da leitura de inúmeros documentos publicados procurou-se retirar elementos informativos que, de modo direto ou indireto, em variados graus de generalização, diziam respeito ao solo. É fácil compreender a dificuldade desta proposta já que quase todos os autores tidos como de formação "naturalista", se preocupam mais com: i) os aspectos fisiográficos relativos a tipos de paisagem e dados geográficos; ii) aspectos da vegetação quanto à tipologia e identificação de espécies; a botânica sistemática era ciência já bem adiantada, e o Brasil incluído no novo mundo, representava um campo imenso a ser estudado. Em menor grau, o mesmo se aplicava à zoologia; iii) aspectos geológicos, litológicos e principalmente mineralógicos abrangendo nomeadamente aquilo que se pode designar por geologia econômica; a potencialidade em recursos minerais do Brasil era tida como incomensurável e o objetivo econômico dominante nos relatórios das viagens de estudo; iv) o conhecimento histórico e principalmente antrópológico dos povos do Brasil pré e pós Cabralino. Os usos e costumes dos indígenas brasileiros de diversas etnias, relações entre si e com o colono europeu, suscitavam enorme interesse dos autores.

Nos textos consultados, cada autor tem uma ordenação própria que geralmente é a do roteiro de viagem, abordando todos os temas ou áreas de interesse em simultâneo segundo os lugares ou regiões percorridas. Desta imensa profusão de informações, é que se procurou retirar algo que dissesse respeito à ciência do solo, o que nem sempre foi conseguido, face às dificuldades apontadas e às nossas limitações. Da enorme bibliografia consultada, não tanto em número, mais pela extensão dos textos, que perfaz mais de 10 mil páginas, obviamente muito deve ter escapado à nossa observação. Por outro lado esta bibliografia está longe de ser exaustiva faltando-lhe várias obras de inegável vulto e interesse, para as quais não houve tempo ou disponibilidade. Entre tantas citam-se as de Hans Staden (Duas Viagens ao Brasil), a Viagem ao Interior do Brasil de G. Gardner, bem como outras não especificadas devidas à T. Ewbank, A. Thèvet, H. Coudreau, T. Koch-Grunberg, além de tantos outros.

\section{OS PRIMÓRDIOS: BRASIL SEICENTISTA}

Há evidências que sugerem que os Índios, assim como muitos povos pré-colombianos, possuíam um conhecimento até surpreendente dos solos onde cultivavam suas roças, à exemplo do descrito por Carneiro (1961) para os índios Kuikúru, e mesmos sistemas de classificação das terras, algo simplificados, para os Xicrins (Cooper et al. 1995) e Macuxis e Uapixanas (Schaefer \& Eden 1995; Quadros 1 e 2), alguns dos quais são utilizados até hoje. Grande parte dos sistemas indígenas de classificação dos solos na América tropical, contudo, permanecem desconhe- cidos, em parte pela negligência dos etnólogos com aspectos ligados ao meio físico, de percepção mais difícil.

Quadro 1: Tipos de solos reconhecidos com base na côr e outros atributos. Dados colhidos com o

Tuchaua, pelo primeiro autor, na Maloca UapixanaMacuxi da Boca da Mata, Serra de Pacaraima.

Table 1: Types of soils recognized by Uapixanal Macuxi indians in Roraima, based on colour and other attributes.

\begin{tabular}{|c|c|}
\hline Nome & Descrição \\
\hline Buro-imek & Solo negro, turfoso \\
\hline Core-imek & Solo amarelado, mais pobre \\
\hline Ueraw-imek & Solo vermelho, mais rico \\
\hline Cada-law & Solo cinzento, gleizado \\
\hline Coba & Solo pedregoso qualquer \\
\hline Ubaracaw-Coba & Solo pedregoso, com quartzo leitoso \\
\hline
\end{tabular}

Quadro 2: Tipos de solos reconhecidos pelos Xicrin, parte da nação Kayapó, Carajás. O prefixo "Puka" significa solo (adaptado de Cooper et al., 1995).

Table 2: Types of soils recognized by the Xicrin (Kayapós) at Carajás. The prefix "Puka" means soils.

\begin{tabular}{|c|c|}
\hline Nome & Descrição \\
\hline Pukaká & Solo branco \\
\hline Pukanrik & Solo vermelho \\
\hline Pukatuk & Solo negro \\
\hline Pukangrãngrã & Solo amarelo \\
\hline Pukakru & Pedra, Solo pedregoso \\
\hline Pukangú & Solo úmido \\
\hline Pukatudji & Solo seco e duro \\
\hline
\end{tabular}

Observa-se, nos sistemas classificatórios acima, e que prevalece ainda hoje nos sistemas adotados, que há uma ênfase grande na côr como atributo diagnóstico, em virtude da facilidade em se observar as cores dos solos, e pelas características próprias que podem relacionar-se à este atributo tão visível.

Com a conquista luso-espanhola, muito deste manancial de informações sobre os solos, do ponto de vista do nativo, foi irremediavelmente perdido. Cieza de Leon, citado por Hyams (1952) em seu interessante "Soil and Civilization" ilustra de modo claro a visão seiscentista dos espanhóis, ao se debruçarem sobre a imensa riqueza cultural dos Incas:

"Nestas terras elevadas e de vastos desertos, as regiões habitadas são os vales amplos, as ravinas $e$ grotas, onde áreas mais planas, de dimensões variadas, abrigam-se da neve e ventos que castigam a cordilheira... Neles, a terra é tão fértil que tudo que se lhes semeia abundantemente se colhe; as águas são de excelente qualidade, e as vilas populosas, onde um povo vive saudável e confortável."

Ou ainda o hino dos Colla, povo do Titicaca (Hyams 1952): 
"Solo, Mãe de todas as coisas, deixa-me ser teu filho..."

Em terras do Brasil, a resenha, não poderia deixar iniciar com um trecho significativo da carta de Pero Vaz de Caminha ao Rei de Portugal:

"Esta Terra, senhor, ... traz, ao longo do mar, em algumas partes, grandes barreiras, algumas vermelhas, algumas brancas; e a terra por cima é toda plana e muito cheia de grandes arvoredos. Mas a terra em sié muito boa de ares, tão frescos e temperados, como os do Entre-Douro e Minho. Águas são muitas e infindas. De tal maneira é graciosa que, querendo-a aproveitála dar-se-á nela tudo por bem das águas que tem. "

Este trecho da carta exaltando as virtudes da terra, revela uma observação que de muito ultrapassa $o$ sentido restrito do solo, como se vê ao reportar sobre a variação de côr das Barreiras, mas sim reportando-se à terra no sentido amplo incluindo as condições ambientais da qual destaca "as águas que tem". Recursos edáficos e hídricos, os primeiros avaliados pela pujança da vegetação nativa, constituíam uma antevisão do que poderia vir a ser a agricultura do futuro. Apesar do equívoco de inferir a capacidade produtiva apenas pelo vigor vegetativo da flora nativa, deve-se recordar que tal costume se tem prolongado desde essa data até nossos dias, tendo ainda hoje seguidores.

Não consta nos relatos de viajantes que se seguiram outras referências ao solo que acrescentassem algo à carta de Caminha. Tomando, por exemplo, a obra de Jean de Lery, verifica-se que dos vinte e dois capítulos que a compõem, perto da metade é dedicada exclusivamente aos usos e costumes dos indígenas (especialmente tupinambás); e os restantes se dividem entre descrições botânicas e zoológicas, além de outros relatos sobre os acontecimentos históricos.

\section{O SOLO BRASILEIRO É CULTIVADO: OS SÉCULOS XVII E XVIII}

Entre o período anterior e a maior parte do século XVI existe um hiato em nossas consultas, que se reportam principalmente ao início do século XVIII. Este período de cerca de um século e meio, corresponde à ocupação efetiva da terra, em termos econômicos ao chamado "ciclo do açúcar", durante o qual houve a expulsão de franceses e holandeses do território. A passagem de uma estrutura puramente extrativista (PauBrasil, madeiras, etc.) para a economia açucareira, de alta rentabilidade, propiciou a efetiva ocupação do território, com estruturas de produção enraizadas e população própria brasileira ou imigrada.

Entretanto, neste período o conhecimento técnico/ científico dos solos não teve real desenvolvimento, devido à precariedade de evolução da ciência como um todo. Contudo em virtude do uso do solo como fator de produção em especial da cana-de-açúcar, houve sim um avanço, deixando-se de lado informações genéricas como "boas terras e águas", para se firmar um esboço de classificação de solos. As terras, ou os solos, correspondentes, foram diferenciados em espécies ou tipos de acordo com finalidades utilitárias, onde são caracterizados morfologicamente no que tange às suas características mais evidentes e detectáveis pelos observadores da época.

Reportamo-nos à notável obra de Antonil ${ }^{(3)}$ como referência dessa época, pois que consubstancia o conhecimento geral a esse tempo. Apresenta-nos Antonil (1711) um esboço classificativo dos principais solos identificados, apropriados ou não para a cultura da cana-de-açúcar. Da obra extraíram-se as seguintes terminologia e descrições:

- Massapés: São as terras negras e fortes, excelentes para a planta das canas.

- Salões: terras vermelhas capazes de darem poucos cortes porque logo enfraquecem.

- Areíscas: Mistura de areias e salões próprios para mandiocas e legumes, mas não para canas.

- Terras brancas ou terras de areia: Impróprias para cana mas que à semelhança das anteriores servem para mandioca.

- Apicus: terras que faz o mar entre si e a terra firme e as cobre as marés e que dão o barro para purgar o açúcar nas formas.

Está claramente expresso que se trata de designativos utilitários, referidos a objetos (solos), identificáveis por observação morfológica sumária. Tais "tipos" são designados pelo autor "castas de terra", transcrevendo-se: "De todas estas castas de terras tem necessidade um engenho real, porque umas servem para canas outras para mantimentos da gente e outras para o aparelho e provimento do engenho...". Antecipa, Antonil, a importância da diversidade dos solos para diferentes fins agrícolas.

Apesar das descrições reduzidas ao mínimo, parecenos simples uma correspondência tentativa entre a nomenclatura do atual sistema de classificação de solos e os termos usados por Antonil:

- Massapé: designação que sobrevive até os nossos dias. São solos de características acentuadamente vérticas, vertissolos propriamente ditos ou solos glei vérticos, com restrições de drenagem, elevada fertilidade natural e alta capacidade de retenção de água, com horizonte A chernozêmico ou não. São os solos ocorrentes nas terras destinadas preferencialmente para as lavouras de cana-de-açúcar.

- Salões: correspondem aos latossolos predominantemente vermelho-amarelos e amarelos, argilosos,

(3) O padre André João Antonil foi um jesuíta italiano que a convite do padre Antônio Vieira veio para o Brasil cerca de 1680 (ou 1667) onde se fixou e faleceu em 1716. Viveu na Bahia onde chegou a escrever o cargo de Provincial da Ordem no Brasil. Preocupado com outros assuntos que não só os de natureza religiosa, publicou monumental obra sobre a economia brasileira em que abordava além do açúcar as produções de tabaco e da então nascente produção de ouro. A primeira edição dessa obra foi publicada em Lisboa em 1711 e mandada apreender quinze dias depois de posta à venda, pois o governo português entendeu que a sua divulgação iria beneficiar concorrentes tais como holandeses, espanhóis e outros. Além disso a revelação de tanto potencial de riqueza iria com certeza despertar a cobiça de outras nações européias. 
álicos ou distróficos, característicos dos tabuleiros litorâneos. A deficiência em fertilidade natural é a sua maior limitação, sendo observado que “...após poucos cortes logo enfraquecem".

- Areíscas: devem corresponder ainda a latossolos dos tabuleiros mas de textura mais grosseira e tidos já como impróprios para o cultivo da cana, porém capazes de produzir culturas de subsistência. São comuns nas áreas mais arenosas dos tabuleiros e barreiras nordestinos.

- Terras brancas ou de areia: como a própria designação indica são areias quartzosas de cor esbranquiçada, totalmente inadequadas para cultivo de cana, mas ainda assim capazes de sustentar culturas de subsistência, entre elas a mandioca.

- Apicus : nome obviamente de proveniência indígena relativo às áreas cujos solos são influenciados pelas marés (manguezais) e que devem corresponder aos solos glei tiomórficos e solos indiscriminados de mangues. Das partes mais altas se extraía o "barro" para purgar (branquear e dar acabamento) ao açúcar.

\section{A RENOVAÇÃO CIENTÍFICA DOS SÉCULOS XVIII E XIX: REFLEXOS NO BRASIL}

A ordenação simplista dos solos no item anterior, deve ter tido outras similares no Brasil, para culturas específicas e/ou regiões agrícolas. Aquela apresentada por Antonil deve ser vista como um modelo exemplar da pré-pedologia brasileira, adotando-se designativos morfológicos e químicos básicos, provenientes do conhecimento empírico, e de implicações no manejo dos solos.

Em meados do século XVIII, os tentáculos da ocupação humana no Brasil, avançaram muito além das áreas litorâneas e das zonas de mineração. Com a decadência das minas, à partir de meados deste século, uma considerável massa populacional, empobrecida e dominada pela mentalidade escravista, dispersou-se por todos os quadrantes da Zona Florestada Atlântica, convertendo em poucas décadas esta extensa área em cenário monótono de pastos degradados e agricultura de subsistência, num quadro desarticulado e sem promessas. Selecionou-se, aqui, um trecho do depoimento do naturalista e mineralogista brasileiro José Vieira Couto $^{(4)}$ (1799), extraordinário pela sensibilidade com os rumos do uso corrente dos solos, e das consequências ecológicas e econômicas em médio e longo prazos:

"Parece que já é tempo de se atentar nestas preciosas matas, nestas amenas selvas que o cultivador do Brasil, com o machado em uma mão e com o tição na outra, ameaça-as de um total incêndio e desolação. Uma agricultura bárbara, e ao mesmo tempo, muito mais dispendiosa tem sido a causa deste geral abrasamento. $O$ agricultor olha em redor de si para duas ou mais léguas de matas como para um nada e, ainda a não tem reduzidas a cinzas, já estende ao longe a vista para levar a destruição a outras partes; não conserva apego nem amor ao território que cultiva, pois conhece muito bem que ele talvez não chegará aos seus filhos;... um áspero campo, coberto de tocos e espinhos, compõe os seus amenos ferregiais; a cultura se estende somente a três ou quatro gêneros de sementeiras, e a lenha principia já a faltar nos lugares mais povoados. Eis aqui, por uma parte, as perniciosas consequências que trazem consigo este mau método de cultivar a terra..." E prossegue adiante: "Pareceme que seria conveniente vedar-se a todos os cultivadores do Brasil, que habitam longe dos povoados, o derrubar e incendiar mais da metade de seus matos; então eles se veriam constrangidos, pouco a pouco, a lavrar e estrumar as terras e o restante dos matos se conservaria em utilidade sua, de seus próprios filhos, e do estado. As propriedades então ficariam mais permanentes, a povoação fixa e não errante, a agricultura tomaria uma melhor face..." Sobre as observações de natureza pedológica, escreve: ... "na altura de 19 graus, com pouca diferença, o viajante que passa da Comarca de Sabará ao do Serro, depois de caminhadas poucas léguas, sensivelmente acorda que o terreno debaixo de seus pés principia mudar-se: de uma terra vermelha, pesada e fértil, que dantes era, ele calca um chão arenoso e coberto de um pedregulho".

As notáveis observações de Vieira Couto sobre o mau uso dos solos e remoção da vegetação florestal são primorosos, e ainda atuais. Retratam grande parte do cenário de subsistência em solos degradados, encontrados hodiernamente na Zona da Mata Mineira, os quais já eram visíveis nos fins do século XVIII.

Nesta época, o celebrado Humboldt ${ }^{(5)}$ (1807), ao sintetizar algumas idéias sobre o desenvolvimento das sociedades e os solos, escreveu:

“O processo de civilização dos povos se dá, quase sempre, na medida inversa da fertilidade do solo em que habitam. Quanto maiores as barreiras naturais a vencer, mais rápido o desenvolvimento das faculdades morais para vencê-los".

A afirmativa é claramente contrária ao que observaram seus contemporâneos brasileiros, e reflete uma visão antropocêntrica da natureza, em voga

(4) José Vieira Couto era brasileiro, nascido no Tejuco (atual Diamantina), Minas Gerais. Membro da seleta elite local, era naturalista, mineralogista e médico, formado em matemática e filosofia pela Universidade de Coimbra, onde destacou-se pela sua erudição e vastos conhecimentos geográficos e mineralógicos. Foi designado pela Coroa portuguesa, para percorrer as áreas mineiras e relatar o estado geral das condições de desenvolvimento das mesmas. Sua familiaridade com a doutrina iluminista pode ser avaliada pela biblioteca que possuía, com cerca de 600 volumes, o que era muito significativo para a época. Seu espírito racionalista era de cunho fortemente não-religioso, e entre seu acervo não se encontrava nem mesmo a Bíblia. Foi uma personalidade típica do último quartel do século XVIII, sob a influência do Marquês de Pombal.

(5) A. von Humboldt, 1807, extraído do capítulo Cultura dos Solos, do livro Voyage de Humboldt et Bonpland - Physique Gènèrale. 
naquele tempo. A pobreza dos solos tropicais parece, em grande medida, determinar o sucesso ou, pelo menos, muitos mecanismos de adaptação ao meio.

Com o advento da época de nova revolução técnicacientífica da humanidade (período pré-industrial), o conhecimento de ciências básicas nomeadamente da química, biologia, mineralogia, se intensifica. Embora o conhecimento dos solos, pelo menos de maneira mais ou menos organizada, não tivesse qualquer progresso, há um amplo registro de observações, que embora desvinculadas entre si, revelam um incremento da profundidade com que eram observados. Tomar-se-á como referência a obra do naturalista Alexandre Rodrigues Ferreira na sua viagem à região amazônica, capitania de S. José do Rio Negro, realizada a partir de 1783 e nos anos subsequientes.

\section{O PIONEIRO NATURALISTA ALEXANDRE RODRIGUES FERREIRA ${ }^{(6)}$}

Rodrigues Ferreira desdobra-se em muitas observações sobre o estado da agricultura da região, principalmente sobre culturas alimentares, mandioca, arroz, milho e feijão mas também das comerciais, café, milho ou mesmo cacau. Tece algumas considerações judiciosas sobre práticas agrícolas, compartilha a opinião equivocada da elevada fertilidade do solo, atribuindo a pequena produção "porque o trabalho a fazer é muito e a preguiça muito mais”.

Ao descrever o Grupo Barreiras, no baixo Rio Negro: “As Barreiras do Rio Negro próximo ao lugar de Moreira constam de: Tijuco(7) (argila vitriolácea) entremeada de barro de ferro amarelo designada por Tauá; argila avermelhada chamada de Curi. Bancos de pedra areenta que se esboroa à menor pressão, situando-se em posição ora superior ora inferior às ditas argilas. A argila queimada muda de amarelo para vermelho. As barreiras na Vila de Tomar são formadas por argila e areia, uma e outra substância carregada de tintura de ferro avermelhada". Há também referências à ocra e tabatinga nos revestimentos das casas. "Nas Barreiras de Lama Longa, consta de areia e argila bastante coradas de ocra de ferro, predominando areia; não se percebem fragmentos metalizados (de ferro), dominando a terra amarela ou já queimada (calcinada); sob estas substâncias aparecem estratos de tabatinga com veios avermelhados". "As Barreiras do Rio Negro junto à vila da Barra (hoje, Manaus): consta de argila avermelhada e vitriolada, a qual se acha incorporada com a areia, com a ocra e com a tabatinga”.
Ressalta-se, ainda, o transcrito: "Com efeito a terra é fértil quanto se pode desejar, porque além do seu fundo consta das duas qualidades de terras, areenta $e$ argilosa, as quais estão misturadas por um modo o mais favorável à vegetação, por outra parte ainda mais o ajuda a outra mistura de terra humosa que é essa terra preta, por outro nome terra de jardins, nas quais se resolvem os vegetais mediante a putrefação que procede das vicissitudes do calor e da umidade”.

Ainda que o autor tivesse vivido na fase da prépedologia (século XVIII), fica relativamente claro hoje reconstruir o perfil do solo que o mesmo descreveu de maneira expressa nas duas últimas observações. Tratase provavelmente de um Latossolo cujo horizonte B ("os fundos") é argilo-arenoso ("terras misturadas") de cor amarela ("ocra") ou vermelha ("ocra avermelhada"), assentando sobre um horizonte C (tabatinga ou argila branca, devendo tratar-se de caulinita com mosqueados de óxidos de ferro). O horizonte A deve corresponder à terra humosa ou preta que o autor também denomina terra de jardins. $\mathrm{O}$ autor relaciona o endurecimento do solo devido às queimadas, perda de sementes e de cinzas pelo vento e pela chuva.

Há, ainda, a notável opinião sobre o extrativismo mineral "versus" agricultura: "que não só não promova o descobrimento do ouro nas serras ... mas que tenha particular cuidado de o impedir por todos os modos diretos e indiretos que possível lhe forem." “...o aumento desse Estado só pode conseguir-se pelos utilíssimos estabelecimentos da agricultura e do comércio e que estes decairão se os povos que neles devem empregar se divertirem para as minas..." “...porque um lavrador sempre vale para o mesmo estado mais que 20 mineiros..."

$\mathrm{O}$ dito acima vale pelo que experimentava então a Capitania de Minas Gerais, em pleno ocaso da mineração, cujo capital perdeu-se entre Lisboa e Londres.

Sobre a cor do Rio Negro: "A causa desta cor de alambre, parece provir dos betumes que encontra o rio nos grandes e multiplicados rochedos por onde passa em quase todo o seu curso descendo das altas cordilheiras de Popaian. Outros querem que esta cor provenha das árvores que inunda por seu todo de ilhas alagadiças, o que não é impossível”. Prossegue em várias considerações sobre a origem da cor, citando mesmo experiências por ele executadas de natureza química: "Por destilação a água saiu clara e diáfana tendo o fundo do alambique ficado negro; com algumas gotas de ácido (vitríolo) sulfúrico, desvaneceu-se a cor escura ficando cristalina.

(6) Alexandre Rodrigues Ferreira, natural da Bahia, estudou medicina na Universidade de Coimbra, além de aspectos da a flora e fauna brasileiras, tendo viajado pelos principais rios da bacia amazônica entre 1783 e 1792. Quando da primeira invasão napoleônica a Portugal, as suas coleções botânicas e zoológicas que se encontravam em Lisboa junto com desenhos e manuscritos, cerca de 18 volumes, foram entregues por ordem do comandante francês Junot a Geoffroy de Saint-Hilaire. Em Paris, usando desse material, o cientista francês publicou vários trabalhos como sendo de sua própria autoria, o que constitui um dos mais evidentes roubos de propriedade intelectual de todos os tempos. O brasileiro morreu sem reconhecimento.

(7) Tijuco designa um depósito argiloso de partículas muito finas de coloração acinzentada ou esverdeada. Parece tratar-se mesmo de sedimentos Barreiras, com ocorrências de camadas intemperizadas; a mudança de cor deve-se à goethita transmutando-se por efeito do calor em hematita. 
As terras que constam na área do rio Negro são: Areia, Tijuco, Tabatinga, Ocra e Curi; na superfície do terreno vêm-se camadas de terra humosa mais ou menos grossas. A título de exercício estabelecem-se tentativamente as seguintes correspondências: vermelho-ferruginosa, que ainda não nos aventuramos a determinar mais exatamente se contém ouro, como dizem”.

Em seguida, uma descrição minuciosa dos materiais de canga em Ouro Preto, com observações mineralógicas

\begin{tabular}{|c|c|}
\hline Nome & Correspondente \\
\hline Areia & Areias Quartzosas e Podzóis Hidromórficos \\
\hline Tijuco & Solos Hidromórficos, orgânicos e gleis \\
\hline Tabatinga & Horizonte C, caulinítico \\
\hline Ocra & Horizonte B de latossolo amarelo \\
\hline Curi & Horizonte B de latossolo vermelho-amarelo ou vermelho escuro \\
\hline Terra humosa & Horizonte A, antrópico ou não \\
\hline
\end{tabular}

As observações de Alexandre Rodrigues Ferreira, credenciam este sábio naturalista brasileiro a ser considerado, junto ao padre Antonil, como um dos precursores da pedologia brasileira.

Restam algumas menções esparsas sobre os solos, em documentos administrativos coloniais, que denotam uma preocupação mais com as potencialidades minerais que com o uso dos solos, como no texto do Ouvidor Vasconcelos (1807):

"Em quase todas as Gerais, aparece ocre amarela, branca e de muitas cores, a que dão o nome de tabatinga, e de que se usa na pintura. Tempo virá (e já não está muito longe) em que homens hábeis farão aproveitar as riquezas minerais ainda intactas e ocultas da Capitania”.

\section{AS VIAGENS DOS NATURALISTAS DOS SÉCULOS XIX E XX. A PRÉ-PEDOLOGIA}

O acêrvo de informações sobre a história natural brasileira, durante o período pré-independência e Imperial, constitui sem dúvida, um patrimônio cultural admirável. No período correspondente ao início do século XIX, é grande o número de cientistas que estudam o território brasileiro. Sem ter a ambição de considerar esta compilação como completa, apresentam-se a seguir as observações efetuadas em alguns dos autores de maior nomeada e que julgamos exemplares desse período.

\section{Da Viagem dos naturalistas Spix e Martius (entre 1817 e 1820) $)^{(8)}$}

Dos três volumes que compôem a Viagem ao Brasil, existem inúmeras referências aos solos e seu uso; destacamos algumas, como esta sobre os solos (latossolos) nas áreas graníticas do Rio de Janeiro:

“...Sobre a formação das montanhas nesta região (Rio de Janeiro), observamos que a terra ora se levanta pouco a pouco ao longo da costa, e o granito forma cadeias de colinas suaves, arredondadas e de alturas desiguais, ora se levantam enormes montanhas cônicas, diretamente do mar. As montanhas são, quase por toda a parte, cobertas por solo bastante forte de argila precisas da sua constituição:

"A primeira camada, aqui chamada tapanhoacanga, é uniformemente espalhada sobre a superfície dos morros de Vila Rica... A massa da jazida consiste em argila mais ou menos avermelhada por óxido de ferro, e sobretudo, com caulinita. Esta última tem cor de telha, passando a parda-avermelhada; em muitos lugares é malhada de azul acinzentado e amarelo-ocra, misturada à ocra pura (goethita). Nessa massa, encontramos pedaços de limonita ocrácea, com pequenas cavidades, preenchidas por precipitação ferruginosa (laterita cavernosa). Há, ainda, pedaços de oligisto (hematita compacta), magnetita e micaxisto, além de drusas de quartzo”.

Comentando sobre o plantio da videira e a pobreza dos solos em nutrientes:

"Talvez as uvas aqui sejam menos doces, porque os solos sejam mais pobres em cal, muito argilosos, e graníticos; ou porque a videira ainda não se tenha aclimatado por aqui”.

\section{Observações de John Mawe}

A preocupação dominante deste autor, dada a sua formação básica e interesses comerciais, era a geologia econômica. O interesse pelos solos, e de suas virtudes agronômicas, é virtualmente inexpressivo, e sempre incluso em descrições de caráter geológico mais geral. À seguir, um trecho sucinto, extraído do livro:

"O solo é geralmente de uma argila forte, os afloramentos rochosos são de granito primitivo, no qual ocorre o anfibólio.... há cadeias de montanhas recobertas de xisto argiloso, onde vimos uma colina coberta de rocha de ferro micáceo (itabirito)...o ferro forma camadas alternadas de uma polegada de espessura alternando com camadas de areia branca... O solo consiste em geral em uma terra vermelha carregada."

\section{Descrições de Eschewege ${ }^{(9)}$ em seu "Pluto Brasiliensis"}

Do mesmo modo que o autor precedente, a preocupação do Barão de Eschewege era a geologia econômica. Apesar do pouco tempo de permanência

(8) Os Drs. Carl Friedrich von Martius, médico e botânico, e Johann Baptist von Spix, zoólogo, eram alemães de Erlanger e Hochstadt, respectivamente; acompanharam o séquito da arquiduquesa austríaca D. Leopoldina, quando empreenderam a notável viagem científica entre 1817 e 1820

(9) W. L. Von Eschewege, barão da cidade do mesmo nome donde era natural (Alemanha) era por formação engenheiro de minas. Fixou-se em Portugal nos primeiros anos do século XIX, vindo para o Brasil em 1810, tendo permanecido até 1821. Homem de grande atividade e talentos - aproveitados largamento pelo governo de D. João VI - foi incumbido de vários projetos em Minas Gerais, entre eles o estabelecimento de fundições de ferro, abertura de minas, estudos mineralógicos, os quais desempenhou com eficiência. Entre muitas obras publicadas em alemão e em português figura como a mais extraordinária o famoso "Pluto Brasiliensis". 
no Brasil em vista do grande desafio que D. João VI o incumbira, teve uma enorme produção científica, onde a pedologia entra como detalhe de menor importância. Veja-se, por exemplo, estas descrições seguintes, sobre as formações de petroplintita (canga) em áreas de itabirito:

"Tapanhoacanga ou canga ${ }^{(10)}$ se encontra freqüentemente nas partes mais elevada das serras $e$ em suas vertentes, assim como nos planaltos inferiores e nas cabeças dos morros, à semelhança de uma crosta sobre as jazidas inferiores do xisto argiloso e do xisto com oligisto (hematita) micáceo. Este grande depósito que propriamente deve ser considerado como uma jazida de hematita, e compõe-se simplesmente de fragmentos quadrados, raras vezes arredondados de oligisto micáceo, de ferro especular e magnético, e de limonita, os quais são ligados uns aos outros na maior confusão por cimento ferruginoso. Estes fragmentos são do tamanho de uma ervilha até de oito polegadas, e maiores ainda...".

"O ferro nativo telúrico, não-meteórico, de cuja existência se duvidou por muito tempo, se encontra no Brasil no conglomerado ferruginoso e que os mineiros chamam de tapanhoacanga”.

No que respeita aos solos mais especificamente, extraíram-se estas observações:

"Esse Distrito Diamantino apresenta, é verdade, o solo mais estéril do Brasil, coberto de morros desnudados e de ásperos rochedos de itacolomito e outras rochas análogas, de modo que nesse terreno ingrato, reduzido a uma simples crosta de terra vegetal, nenhuma árvore ou arbusto pode fixar suas raízes, nem os homens e animais encontram uma vida fácil."

Essas observações ajudam a esclarecer as dificuldades alimentares da população, em especial dos escravos, àquele tempo de exploração intensiva de ouro e diamantes, na Comarca do Serro Frio.

O solo muitas vezes equivale ao conceito de "terra vegetal", e quase nunca é objeto de descrição. Mesmo esta "terra vegetal", teve conceituação bem diversificada, correspondendo desde uma simples camada intemperizada superficial até todo o manto inconsolidado, regolito, repousando sobre a rocha. Veja-se a seguinte descrição:

"A terra vegetal apresentava três camadas. A superior era uma terra vermelha e fértil com uma espessura de 12 palmos; a segunda um depósito de argila esverdeada misturada a uma argila branca com uma espessura de 14 palmos; a terceira de 20 palmos de espessura...consistia em uma argila negra”. Note-se que só a primeira camada da terra vegetal tinha cerca de $2,5 \mathrm{~m}$ de profundidade $(1$ palmo $=22 \mathrm{~cm})$, com um total de espessura sobre a turfa de aproximadamente $10 \mathrm{~m}$.

"A terra vegetal se apresenta nestes lugares em espessas camadas de uma argila ferruginosa...” ou: “A terra vegetal nestas alturas forma uma camada pouco espessa sobre a rocha..."

"Seco e árido nesta região, o solo aqui apresenta apenas uma vegetação rasteira cobrindo espessas camadas cortadas em todos os sentidos por profundas erosões e escavados, de solos graníticos argiloferruginosos, em quase toda a sua extensão friáveis..."

Trata-se, acima, de uma notável observação sobre a friabilidade e erodibilidade dos cambissolos originados de granitóides, como os que ocorrem na região de Cachoeira do Campo e Gouvêia, entre outras, onde são abundantes as voçorocas, às quais se refere o autor.

Não deixa de ser curiosa a seguinte observação: “...porque mostrando em geral a coincidência da vegetação com a das rochas, estas para leste pertencem às rochas graníticas que se decompõem facilmente na superfície e tornam-se férteis, enquanto as para oeste são pela maior parte compostas das xistosas, que deixam um terreno ou argiloso, ou arenoso, e sempre estéril. Esta razão porém não é ainda satisfatória porque há nas regiões dos campos extensões de muitas léguas de rochas graníticas sendo o solo estéril como se elas fossem xistosas, havendo ao contrário rochas xistosas em grandes extensões produzindo solo fértil." Aqui uma observação pioneira de que a composição química das rochas de estrutura semelhante é variável, o que se reflete na fertilidade distinta para composições distintas. Provavelmente, as rochas de caráter granítico reportadas, variam desde granodioritos (ou mesmo diabásios, com solos melhores) até granitóides felsíticos, onde a erosão e pobreza química eram extremas. Essas relações solo-planta-litologias estão, ainda hoje, a merecer maior destaque e pesquisa por parte dos pedólogos, embora a compreensão dessas relações tenha avançado muito nos últimos vinte ou trinta anos.

\section{Observações de Pohl}

Podem ser citadas, ainda, observações de natureza pedológica, do sábio austríaco Johann Emanuel Pohl (1832), em seu Viagem no interior do Brasil ${ }^{(11)}$. Comentando sobre o Rio Araçuaí e a fertilidade dos solos do semi-árido mineiro, diz-nos Pohl:

"No mesmo dia, continuamos a nossa viagem rumo ao leste, pela margem do rio Araçuaí, então raso, mas largo e profundo no tempo das chuvas, do qual apenas por momentos éramos separados por morros. A região tornou-se maravilhosa de fato, especialmente pelas muitas e bem instaladas fazendas que devem a sua multiplicação não só à fertilidade do solo como também à circunstância de ter o governo dado a cada colono meia légua quadrada de terreno com isenção de impostos por dez anos. Este tipo de fazenda tem o nome de Roça Grande."

(10) Atualmente corresponde ao conceito de plintita endurecida, petroplintita, na ciência dos solos. Nas geociências costuma ser designada laterita, couraça ferruginosa ou mesmo canga.

(11) Do capítulo do livro Viagem pelo rio Jequitinhonha, via são Miguel, a Salto Grande e à Aldeia do Alto dos Bois, entre 1817 e 1821 (extraído do livro de Pohl, 1832, "Plantarum Brasiliae icones et descriptiones", onde consta o diário/relato "Viagem no interior do Brasil"). 


\section{A obra de Saint-Hilaire , uma "Pedologia Intuitiva"}

Em Saint-Hillaire ${ }^{(12)}$, vamos encontrar observações valiosas, e ainda hoje válidas, sobre muitos aspectos ligados ao solos e seu uso. Sobre a região montanhosa em Minas Gerais, escreve o autor:

"Ao alcançar-se certa altura na Serra, muda o terreno de aspecto. Depois de ter sido argiloso, não ostenta senão rochedos ou areia quartzosa branca e grosseiramente pisada”...O terreno aqui é desigual, quase continuamente árido e massas de rochedos erguem-se aqui e acolá. Aqui o solo produz somente ervas e subarbustos... Os arredores apresentam um solo árido e não produzem nem mesmo os gêneros ncessários à subsistência dos habitantes."

Ou nas palavras de grande envergadura, abaixo, antecipando muitas das inferências da moderna pedologia, talvez pela sua grande intuição e sensibilidade, e fazendo coro ao brasileiro Vieira Couto:

"A terra é avermelhada e mais vigorosa nos terrenos primitivos do que nos de formação mais recente: as matas crescem nas montanhas de granito, de gnaisse, de xisto micáceo e de rochas cristalinas, $e$ as pastagens naturais e os arbustos tortuosos encontram-se nos terrenos cuja base se compõe de xisto argiloso,e xisto de ferro (itabirito). Mas se as grandes diferenças de vegetação que se observam na Província de Minas Gerais coincidem com as diferenças da constituição mineralógica do solo, não é menos verossímil, que não são estas últimas que modificam o conjunto das produções vegetais... mostrou-se que a natureza mineralógica dos diversos terrenos não exerce uma influência tão definida sobre a vegetação, ou que pelo menos sua ação é pequena; ... nas vizinhanças do Rio São Francisco, por exemplo...terrenos calcários de formação antiga estão descobertos em certos lugares, enquanto que noutros eles produzem uma vegetação rica e densas florestas. $O$ que numa mesma latitude e em altitudes semelhantes, modifica verdadeiramente a natureza das produções vegetais, é a exposição do solo, o maior ou menor grau de umidade que ele encerra, a subdivisão mais ou menos sensível de suas partículas, a quantidade maior ou menor de húmus que cobre a superfície."

Estas interpretações das relações solo/vegetação nativa, guardadas as devidas proporções, são de um avanço imensurável para a época. A obra de SaintHilaire, omitindo-se alguns raros equívocos, é das mais ricas em observações argutas e comprováveis, sendo dotadas de senso crítico agudo e um saber "intuitivo".

Em seu "Viagem pelas Províncias de Rio de Janeiro e Minas Gerais”, Cap. XIII “Viagem do Tijuco
(Diamantina) ao Morro de Gaspar Soares pela Serra da Lapa” (1830), encontramos:

“...No lugar chamado Três Barras, o terreno que, desde Tijuco ${ }^{(13)}$, havia sido constantemente arenoso, tornou-se argiloso e avermelhado. Então a vegetação muda e os grandes fetos que nascem por toda parte indicam que esses lugares foram outrora cobertos de florestas. Entretanto as areias reaparecem logo e com elas as plantas que lhes são peculiares, Eriocaules, Melastomatáceas de folhas pequenas etc. Mais perto de Vila do Príncipe a terra torna-se novamente argilosa e avermelhada; os vales são mais profundos e foi então que entrei na zona das florestas, da qual me afastara ao distanciar-me das margens do Jequitinhonha e da região dos índios selvagens. Após vários meses, somente tinha sob as vistas rochedos pardacentos $e$ ervas queimadas pelo sol. Compreende-se facilmente a satisfação que experimentei ao rever fetos árboreos, reencontrando bela verdura, sombra e frescura.

... Após haver atravessado durante alguns instantes um grupo de árvores pouco altas, achei-me repentinamente sobre um terreno descoberto, como se as árvores tivessem sido plantadas pelo homem, em limites certos. Um terreno de natureza diferente produziu tal mudança. Na parte arborizada o solo é argiloso misturado com areia e alguns calhaus; na parte descoberta, vê-se ao contrário uma terra negra misturada com muita areia, e rochas arredondadas aparecem aqui e acolá, à flor da terra.

...Toda a região que percorri até cerca de légua e meia de Tapera, apresenta ainda uma alternativa de matas-virgens e terras descobertas, eriçadas, aqui e acolá, de rochedos; mas nas cercanias da aldeia, o solo torna-se mais argiloso e somente se vêem matas; entretanto elas não tem grande vigor, o que é sem dúvida devido à areia que se mistura à terra em grande proporção... Não é também a agricultura que mantém a população atual de Tapera. As terras das redondezas são muito arenosas para serem boas; o milho não dá mais de 100 a 150 por 1, a cana-de-açúcar, que havia sido experimentada, crescia tão pouco que sua cultura foi abandonada".

E avançando nas considerações sobre o mau uso da terra e a degradação dos solos, escreve, fazendo coro ao brasileiro Viera Couto (1799), alguns anos antes:

"Não é crível que todos estes montes despojados de sua antiga vegetação devam essa perda às culturas. Aconteceu aqui a mesma cousa que em muitos outros lugares onde existiam minerações. Os descobridores e exploradores dessas minas quiseram por a zona a descoberto e, para chegarem tal fim, incendiaram as florestas.

(12) Auguste de Saint-Hilaire é talvez o mais popular dos cientistas que visitaram o Brasil durante o Reinado. Sua obstinação e rigor científico, durante os anos de permanência no Brasil (1816 a 1822) lhe permitiram elaborar uma das mais impressionantes e extensas obras sobre a história natural brasileira que se tem documentado, com abrangência multidisciplinar, versando sobre aspectos etnográficos, botânicos, zoológicos, geográficos e históricos com igual competência. O herbário por ele reunido consta de mais de 30 mil números, com mais de 7 mil espécies diferentes. Publicou em vida obra vastíssima, do qual o mais notável é o volume Flora Brasilae Meridionalis, o maior repositório de dados coligidos no Brasil.

(13) Atual Diamantina. 
"Toda esta região foi outrora coberta de florestas, como a que se atravessa entre Tapera e Congonhas; mas aqui não foram os pesquisadores de ouro que destruíram as matas. Como a terra é pobre, surgindo as samambaias desde os primeiros anos de lavoura, foram precisos poucos anos para transformar a região em pastagens. Os campos que atravessei entre Congonhas da Serra e Casa do Barreto diferem muito das pastagens artificiais que se vêem entre $S$. Miguel do Mato Dentro e Vila do Príncipe. As gramíneas aí dominam ainda mais, no meio delas aparecem outras plantas, em números mais considerável. Já tive ocasião de fazer observar que o aspecto dos campos artificiais que se formam em lugares muito elevados é sempre esse. O capim gordura e o sapé parecem não ter tanta força como ao pé das montanhas, ficando incapazes de manter à distância os outros vegetais. Ademais sou mais inclinado a atribuir essa diferença menos a uma elevação maior, que à inferioridade do solo, e o que parece prová-lo é que, entre Congonhas e Casa do Barreto, o terreno, de uma cor quase negra, contém grande mistura de areia.

A habitação de Barreto fora outrora, uma importante fazenda; mas todas as suas terras foram sucessivamente cultivadas e atualmente não servem senão para pastos, se se seguir obstinadamente o sistema de agricultura usado pelos brasileiros...As cinzas escassas das gramíneas não fornecem um adubo abundante e a pronta infestação de ervas daninhas, nesta região úmida, abafam logo os milharais novos. Se se adotar aqui o emprego da charrua e dos adubos, tudo mudará, em breve, de aspecto; e em vez de uma erva inútil, esta região alta e pouco seca produzirá em abundância... (17 de novembro de 1817)".

Assim, em poucas linhas, constata Saint Hilaire que a pobreza química dos solos brasileiros, aliada às práticas de manejo e uso do fogo, levam à necessidade premente do uso de corretivos e da mecanização. Devemos observar que a região, passados mais de 180 anos da viagem do naturalista, ainda padece dos mesmos males, sendo limitada em seu desenvolvimento pelos mesmos fatores do meio, atuantes hodiernamente.

Sobre os solos orgânicos das areias brancas possíveis Podzóis, e a notável convergência de tipos de vegetação de campo de altitude, associado, menciona-se o trecho a seguir:

"Em uma parte da serra observei que o solo se compunha de uma mistura variável de terra preta e areia branca e duvido que toda a montanha não apresente uma mistura semelhante. Desde o momento em que escalei a serra até o em que comecei a descer de modo sensível, atravessei várias chapadas perfeitamente distintas, mas todas igualmente cobertas de pastagens herbáceas. Já havia observado uma vegetação da mesma natureza nos planaltos de todas as altas montanhas onde havia herborizado até então; a Serra de N. Sa Mãe dos Homens, as da Penha e Curmataí, o Serro Frio, próximo de Bandeirinha, enfim a Serra de Santo Antônio próximo a Congonhas.
Lembro-me que mais tarde encontrei pastagens semelhantes nos altiplanos da Serra da Canastra, dos Pirineus, Ibitipoca, do Papagaio, e por conseguinte acredito que se pode, sem riscos de enganos, considerar esse tipo de vegetação como pertencendo aos planaltos das mais altas montanhas do Brasil.

O primeiro planalto que encontrei na Serra da Lapa é ondulado, vasto e rodeado de pequenas elevações onde a rocha se mostra a descoberto. Em certas partes o solo é muito pantanoso, e a planta dominante é uma Ciperácea muito grande, cujas folhas apresentam um caráter notável, tal o de ser disposta em três fileiras longitudinais

Todas as vezes que atravessei florestas, virgens, depois de ter percorrido durante algum tempo regiões descobertas, experimentei um sentimento de profunda admiração. É aí que a natureza mostra toda a sua magnificência, é aí que ela parece se desdobrar na variedade de suas obras; e devo dizer com pesar, essas magníficas florestas foram muitas vezes destruídas sem necessidade".

Ainda em Saint-Hilaire,(1830) - em seu "Viagem pelo Distrito dos Diamantes e Litoral do Brasil”, vamos encontrar notáveis observações sobre a agricultura em contraste com a atividade minerária:

"Entretanto, desde que a agricultura substituiu nessa região as explorações minerais, tudo teve naturalmente que tomar novo aspecto. O cultivo da terra estabelece uma igualdade de fortuna que não poderia, absolutamente, ser o resultado do trabalho aventuroso dos mineradores. Não há no termo de Minas Novas tantas pessoas ricas como em muitas outras partes da província; mas também existe aí menos miséria. Não se vêem em absoluto, como em torno de Vila Rica, povoações quase abandonadas, e fazendas caindo em ruínas. Os colonos vestem-se aí com tecidos muito grosseiros; mas não trazem a roupa em farrapos e como os panos de algodão são aqui muito baratos e grande número de habitantes fabricam-nos em sua própria casa, os próprios negros andam mais bem vestidos do que em outros lugares. No entanto, é preciso que se diga, um obstáculo opõe-se ao bem estar dos habitantes dessa região; é o costume que há de venderse tudo a crédito. Os cavalos e escravos se compram a prazo de vários anos".

$\mathrm{Ou}$ comentando sobre o ouro nos arredores da cidade de Serro e a ocorrência de Latossolos Roxos:

"O ouro dos arredores de Vila do Príncipe é de linda cor. As vezes encontramo-lo disposto em veios, porem, na maioria das vezes, está disperso na terra argilosa de que compõem os morros circunjacentes a aquele em que a cidade está edificada.

Essa terra é de um vermelho carregado. A poeira que ela forma suja muito facilmente o interior das casas, as vestimentas e a roupa branca, e para conservar algum asseio, são necessários cuidados permanentes".

Discorre ainda, sobre as relações solo-vegetação, sugerindo uma estratificação fitogeográfica e sua 
correlação com unidades pedogeomorfológicas:

"A pequena distância de Temerão, observei um novo exemplo da influência da constituição do solo sobre a vegetação. Passei por um morro denominado Morro Pelado, cujo cume é muito arenoso. De repente, a vegetação de grande porte desapareceu de minhas vistas, e a terra não me ofereceu mais que arbustos tais como Cássias e Melastomatáceas. Entretanto, depois de caminhar cem passos, vi a natureza do terreno mudar bruscamente, e sem menor transição, as grandes matas se mostraram com nova pompa".

Essa região pode ser dividida, conforme sua vegetação natural e a elevação das diversas partes, em quatro zonas bastante variadas, mas perfeitamente distintas. Ao oriente, a das florestas estende-se sobre a fronteira, de sudoeste a nordeste; depois dela vem a região dos carrascos, que é muito elevada, e onde o frio se faz sentir fortemente nos meses de junho e julho; as das caatingas, muito mais quente e tão adequado ao cultivo do algodão, está situada às margens do Araçuaí e entre este último rio e o Jequitinhonha; finalmente, a região dos campos".

E comentando sobre a importância da matéria orgânica do solo na capacidade de produção dos mesmos, prossegue o autor:

"Não descreverei todas as variantes de solo e vegetação que se observam entre Mundo Novo e a povoação de Penha; todavia não posso deixar de dizer algo a respeito do morro muito afamado que tem nome de Morro do Indaiá. Este monte, situado a cerca de légua e média de Penha, é elevado, e seu cume forma uma vasta planície em que a terra arenosa não produz senão ervas, subarbustos e alguns arbustos enfezados... Os gêneros que nas matas, fornecem árvores e grandes linhas, não produzem aqui senão plantas de porte anão. Existe em volta de Penha, terras que não se podem cultivar, de tal forma são áridas, e contém pouco humus vegetal; mas, de outro lado de um dos morros que dominam a povoação, existem grandes florestas que se ligam com as de Passanha, e é aí que está estabelecida a maior parte dos cultivadores do lugar. Plantam arroz, milho e feijão, gêneros que se vendem facilmente no Distrito Diamantino".

Sobre a relação solo-vegetação e a ocorrência dos Latossolos e outras classes de solos menos desenvolvidas, e no perigo de tentarmos estabelecer generalizações onde existem nuances sutis, por vezes imperceptíveis:

"Disse, ainda há pouco, que a vegetação era mais variada quando os campos se deviam unicamente a mudanças na natureza do solo que, de fértil se torna ferruginoso, pedregoso ou saibrento. Todavia, observa-se também variedade nas chapadas que se compõem de boa terra; e podese ser levado a pensar que diferenças de exposição e mesmo algumas gradações na natureza do solo sejam as causas principais. No entanto, é preciso notar outras causas que se não podem descobrir; pois que vi modificações na natureza dos vegetais com a mesma exposição e em terreno que me parecia também ser sempre o mesmo, enquanto que, noutros lugares, diferenças de solo bastante sensiveis não produziam a mais leve mudança na vegetação".

\section{Notas de D'Orbigny ${ }^{(14)}$}

Observa D'Orbigny as espessas coberturas latossólicas, onde ocorrem linhas de pedra, com fragmentos angulosos ou não.

"As terras...são compostas principalmente de gnaisse ou gnaisse-granito, sobre o qual se sobrepõem espessas camadas de terra vermelha."... “O terreno de primeira formação é um banco de pedra ferruginosa, na qual se encontram fragmentos de quartzo branco, redondo em parte, em parte anguloso, ao qual se encontra misturado um pouco de gris (laterita). À pequena profundidade encontrase gnaisse imitando granito (saprolito)...Acima e abaixo há diversas camadas de um sedimento, de um vermelho cor de tijolo ou ocre amarelo; os quais pertencem à uma formação muito extensa que encontramos em diversos lugares de Minas Gerais..."

\section{Notas de J. T. Tschudi ${ }^{(15)}$}

Sobre a fertilidade dos solos e sua importância no sucesso dos assentamentos, e ainda algumas interessantes observações sobre a côr, como critério diagnóstico da fertilidade química dos solos, com grande acerto nas observações; observou a importância da côr vermelha (ligada à hematita), associada aos solos de maior riqueza química, e da influência da matéria orgânica na fertilidade :

"A algumas das famílias couberam no sorteio terras tão estéreis e pedregosas que nem uma horta era possível cultivar nelas. ...outras radicaram-se como agricultores nas férteis regióes de Cantagalo até as margens do Rio Paraíba."

"Esta terra roxa (uma argila rica em ferro) é tida como extremamente fértil ... a terra vermelha de colorido menos intenso é menos estimada; dizem os lavradores que ela produz apenas a metade do que produz a terra roxa. A terra branca é reputada a menos fértil de todas, pois, dizem, produz a metade

(14) Alcide D'Orbigny, naturalista francês, a serviço do Museu de História Natural de Paris, percorreu uma boa parte da América do Sul, a partir de 1826, por cerca de 5 anos. A maioria dos dados recolhidos incluem informações geográficas, geológicas, etnográficas e paleontológicas. (15) O Barão João Tiago Von Tshudi, naturalista, médico de nacionalidade suiça e estudioso da América do Sul, tendo inicialmente vivido no Peru durante cerca de 5 anos. Mais tarde, a partir de 1857, visitou também diversos países sul americanos, inclusive o Brasil, onde se fixou depois de 1860 como ministro plenipotenciário da Suiça. Permaneceu no Brasil até 1866 tendo então, e no exercício das suas funções, percorrido o país, em especial a parte sul. 
da vermelha, a terra negra, massapé preto... é particularmente propícia ao cultivo de cana-deaçúcar".

Quanto ao restante dos autores, não há em outras obras clássicas do período, como aquelas de J. M. Rugendas ${ }^{(16)}$ e J. B. Debret ${ }^{(17)}$, maiores menções aos solos, apenas registros esparsos do tipo: "O solo é de argila dura e recoberto de fragmentos de quartzo." ou “... o solo é fértil e bem cuidado."

\section{OS ÚLTIMOS DECÊNIOS DO SÉCULO XIX: PRÉ-PEDOLOGIA DA FASE IMPERIAL}

Incluiu-se nesta fase os trabalhos de cientistas posteriores a cerca de 1860 , em data já mais próxima do nascimento da ciência do solo. Diga-se contudo que embora o nascimento seja reconhecido na década de 1880 , a sua divulgação pelo mundo, nomeadamente no Brasil, fez-se já no século 20. Não há, ainda, avanços significativos na descrição do solo, continuando a referirem-se-lhe através de designações genéricas e considerando-o como uma camada superficial de pouca importância face aos substratos geológicos. Às vezes, contudo, certos autores denotam uma preocupação maior com os solos, com observações bem ponderadas e precisas. São exemplares do período, os brasileiro Costa Sena e Theodoro Sampaio, e o globe-trotter inglês Burton $^{(18)}$, além de sábios como Charles Hartt e L. Agassiz. Deve destacar-se que, em 1887, por decreto do Imperador D. Pedro II, criava-se a Estação Agronômica de Campinas, embrião do futuro Instituto Agronômico de Campinas. ${ }^{(19)}$

Ao lado de ilustres sábios estrangeiros, figuram pioneiros brasileiros, como Costa Sena ${ }^{(20)}$ (1883) em sua pequena mas brilhante "Notícia sobre a Mineralogia e Geologia de uma parte do Norte e Nordeste da província de Minas Gerais". Sobre as cornijas abruptas que bordejam as chapadas do Jequitinhonha e as cangas, exploradas com minérios de ferro:

"Por uma vasta planura, pouco acidentada, chegase ao córrego do Jacú. A chapada, que se prolonga para $O$ e $N$, é para E violentamente cortada, quase na vertical, pelo leito do rio Setúbal, um dos grandes afluentes da margem direita do Arassuahy. O vale que medeia entre chapadas e a serra da Fábrica deixa ver nas camadas a disposição seguinte: Na parte superior se acham quartzitos um pouco arenosos, quase sem mica, dirigidos N. $65 \mathrm{E}$, com uma inclinação de $60^{\circ}$ para S.E., em relação aos itabiritos que deram lugar à formação de pedaços de canga que se encontram na estrada, e donde extrahe-se minério para a forja do Sr. F. de Paula Mattos".

Aliada às observações de caráter geológico, figuram outras, como esta notável observação sobre a fertilidade dos solos sob caatinga, da depressão Araçuai-Virgem da Lapa:

“A zona banhada por este rio, pelo Gravatá e baixo Arassuahy forma o que chamam geralmente a região das caatingas, nome dado às matas de vegetação pouco desenvolvidas, mas de grande fertilidade, que acompanham por muitas léguas o curso do Jequitinhonha”.

E ainda sobre o notável gradiente clímato-botânico do Jequitinhonha até o Mucuri, fazendo referências aos solos como "terra vegetal":

(Para o sul) "a vegetação acanhada das catingas começa a desaparecer. As chapadas tornam-se mais raras e relativamente menos extensas, destacando-se entre todas a do Lagoão, a 430 metros acima da cidade. o gneiss sobre o qual correm pequenos cursos d'água éfácil reconhecer por seu aspecto e schistocidade, mais ou menos pronunciada. Vê-se muitas vezes a pastagem em cima de três ou quatro palmos de terra vegetal, provenientes das rochas subjacentes. Chegando-se ao rio S. João Grande, cujo leito se acha 200 metros acima do Arassuahy, entra-se nas matas gigantescas da serra do Chifre, nas vizinhanças das vertentes do Mucury. A vegetação é sobretudo admirável em grandes bacias cercadas de rochas gneissicas, cujos picos se mostram de longe em longe, até se perderam na Serra do Mar".

Outros autores consultados apresentam resumidamente várias citações de idêntico teor: Abaixo, alguns dos trechos do relato de viagem de Richard Burton:

\section{Notas de Burton}

“... encontrou camada argilosa em contato imediato com o piso de rocha cristalina e observou que quanto mais espessa é ela, mais viçosos são os cafeeiros. Ela

(16) Johann Martinez Rugendas veio ao Brasil na expedição Langsdorff, que abandonou logo de início, viajando depois por conta própria. Tratava-se do desenhista oficial da expedição e os trabalhos produzidos são desta natureza, quadros e figuras acompanhadas de copiosa descrição. Os temas abrangidos foram quase exclusivamente paisagísticos e principalmente humanos, com ênfase nos usos e costumes. (17) Jean Baptiste Debret, denominado "desenhista histórico", fez parte da missão francesa que, em 1816, chegou ao Brasil, tendo permanecido até 1831. Não se limitou, simplesmente, ao desenho, tendo abodado muitos aspectos de natureza social, política, geográfica, de que produziu abundante material.

(18) Richard Burton, famoso explorador inglês que viveu no Oriente e na África. Nos anos 60 foi cônsul da Inglaterra em Santos e durante a sua permanência no Brasil efetuou algumas viagens pelo interior. Homem de comportamento excêntrico, dominava cerca de 25 idiomas entre línguas e dialetos, citando-se o árabe, o industani e o persa e muitas européias. Entre os feitos mais destacados têm-se uma viagem a Meca, na época desconhecida na Europa, a tentativa de descoberta das nascentes do Rio Nilo, a tradução para inglês das "Mil e uma Noites", além de versão traduzida de "Os Lusíadas". Suas observações denotam o ecletismo e inteligência do autor, cuja capacidade de observação era impressionante.

(19) No relatório anual de 1889 da Estação, Dafert \& Uchôa Cavalcanti já escreviam, "Sobre as Terras do Estado de São Paulo": "Antes de iniciar-se qualquer experiência sobre o desenvolvimento das plantas no país, será necessário obterem-se informações sobre a natureza dos solos e o caráter do clima"

(20) Joaquim Cândido da Costa Sena, preparador de mineralogia da Escola de Minas de Ouro Preto, produziu obra de vulto na geologia mineira, publicando seguidamente nos Annaes, como o trecho citado, tirado dos Annaes da Escola de Minas de Ouro Preto, vol 2, pp 113136, 1883. 
determina a fertilidade do solo devido à grande variedade de elementos químicos que contém e do processo de compressão a que esteve submetida sob gigantesca camada de gelo."

"Essa singular fecundidade do mundo vegetal costuma iludir o estrangeiro dando-lhe a idéia da superfície, de maneira a se alimentarem de cada centímetro disponível de húmus muito raso, e os raizames pouco profundos dos gigantes vegetais tombados revelam que nenhum deles conseguiu penetrar na argila ferruginosa das enormes camadas de argila vermelha, cujo núcleo de gnaisse muitas vezes fica a poucos pés abaixo da superfície do solo. E quando aquelas árvores são cortadas, são substituídas por uma vegetação mais pálida, mais amarelada que revela logo a pobreza do solo...no campo, há um solo pedregoso e de capim enfezado..O solo afeta muito a vegetação.

“...as formações superficiais são de quatro espécies. A melhor é o rico terreno aluvial ferruginoso, cor de chocolate, tendo por base uma pedra calcária de montanha, cinza-azulada, cortada por linhas de um branco de neve; a segunda é a terra vermelha, sustentada pelo mesmo material calcário. A macia marga aluvial de cor preta, considerada a primeira no Mississipi é aqui a terceira. E a pior é o terreno branco sem ferro, queimado pelo sol, arenoso. (Margens do Rio das Velhas)".

O autor parece descrever, acima, uma sequência de vertissolos - podzólicos vermelho-escuro eutróficos, cambissolos e areias quartzosas, estratificando-os pela fertilidade, e com base na côr. Sobre os solos plínticos, escreve Burton:

“...o solo era sarapintado, manchas de areias brancas como caulim, ou manchas de humo e de ocre e hematita, sobre uma terra de um marrom avermelhado, mais vivo; esta última é relativamente fértil e revestida de cinza escura.."

Em seguida, ao reportar-se aos latossolos, ocorrentes em descontinuidade sobre o arenito, comenta sobre o horizonte A e, acertadamente, deduz que o período pós-glacial foi marcada por extenso alagamento, em muitas áreas dos trópicos, observação corroborada pelos mais recentes estudos:

"Sobre os arenitos descansam as formações argilosas, laminadas, estratificadas ou não, com linhas e ondulações de fragmentos grosseiros e seixos, cuja constituição é quartzosa, muitas vezes altamente ferruginizada. Sobre o conjunto está a argila arenosa ou pegajosa, vermelha-amarela, ocre, comum no Brasil e África intertropical. Ela se espalha sobre a superfície ondulada de arenito desnudado, acompanhando todas as irregularidades e enchendo os sulcos e depressões. $O$ fim do inverno geológico (glaciação) $e$ desaparecimento final do gelo formaram um vasto lago de água doce."...o material de argila compacta de muitas cores, branca e marrom, avermelhada ou amarela, é recoberta de fina camada de húmus, de superficie."

Há trechos em que Burton discute os aspectos de fertilidade dos solos, relacionando com clareza seu aumento com a presença de calcáreo, ou sua redução, quando a argila é oxidada (ferruginosa) demais:

"...e apresentava um mato ralo em uma argila vermelha, ferruginosa demais para ser fértil sem cal."

"...o solo é coberto de uma areia funda cor de ferrugem e pouco depois... por uma argila vermelha cor de sangüe; tinha manchas de cal e devia ser fertilíssima."... A superfície era arenosa, com plataformas de lajes, com blocos compactos ou dispersos de carbonato de cálcio lembrando mármore. Não poderia haver nada melhor que este solo..."

\section{O sábio Agassiz não atenta aos solos}

Da obra deixada por L. Agassiz ${ }^{(21)}$ após sua estada no Brasil, do ponto de vista pedológico, pouco acrescenta em relação às obras antes citadas; veja-se por exemplo:

“...tem uma coloração particular ( o solo); é um rico e quente tom vermelho que brilha sob a massa das plantas..."

Agassiz teve uma preocupação particularmente voltada à origem do drift, observado nas proximidades do Rio de Janeiro. Transcreve-se: "Numa longa excursão hoje realizada, tivemos oportunidade de observar grande quantidade de blocos erráticos sem conexão alguma com as rochas in loco, tal como uma camada de "drift" glacial misturada com seixos repousando imediatamente sobre a rocha metamórfica incompletamente estratificada."

Como hipótese, defende a existência do período glaciário, como responsável pelo "drift" ou camada de argilas sobrepostas às linhas de pedra, desde a região amazônica até o sul. Não é o escopo deste trabalho um maior desenvolvimento do tema, pois que o solo no sentido pedológico, continua sendo ignorado. Contudo, transcrever-se-ão alguns parágrafos mais ou menos elucidativos da questão e do pensamento do autor.

“....minha atenção foi imediatamente atraída por uma formação particular, uma argila arenosa ocrácea extremamente ferruginosa...tive ocasião de estudar este depósito. Vi que ele assenta com toda a parte sobre a superfície ondulada de uma rocha sólida local; que é inteiramente desprovido de estratificação e contém certa variedade de blocos e seixos."

"Os cortes abertos para a construção da via férrea produziram seções que põem admiravelmente a descoberto a massa homogênea e não estratificada da argila arenosa avermelhada deitada sobre a rocha sólida, sendo a separação entre ambas às vezes

(21) Louis Agassiz, com o apoio pessoal do Imperador D. Pedro II, chefiou uma expedição científica norte-americana que em $1865-66$ percorreu boa parte do Brasil. Era zoólogo de formação, mas com abrangência em todas as ciências da natureza. A equipe diversificada que chefiou (mais de uma dúzia de cientistas), abordou nos seus percursos variadíssimos temas nomeadamente além da ictiologia, a geologia, botânica e como não podia deixar de ser a etnografia, história, etc. 
nitidamente traçada por um leito pouco espesso de seixos...Estava eu entretanto longe de prever quando pela primeira vez os encontrei nos arredores do Rio, que mais tarde os encontraria estendidos à superfície do Brasil, de norte a sul e de leste a oeste, com uma continuidade que faz da história geológica do continente sul-americano um conjunto de fácil reconhecimento"(22).

"Freqüentemente é verdade, a decomposição da rocha subjacente em larga área e às vezes a considerável profundidade, só permite a custo distinguir entre esta rocha e o "drift".

"À primeira vista poder-se-ia crer que ela se mostra no Amazonas idêntica ao que é no Rio de Janeiro; mas difere-se desta na raridade dos blocos e nos traços de estratificação que ocasionalmente apresenta. ${ }^{(23)}$... "Quanto mais se considera o Vale do Amazonas e seus tributários, tanto mais nos convencemos de que a argila avermelhada designada pelo nome de "drift" é um depósito que as geleiras descidas dos Andes abandonados nesses pontos..."

\section{A contribuição de Hartt no Brasil}

Entre as muitas notas do sábio Charles Frederick Hartt, em seu "Geology and Physical Geography of Brazil"(1870), figuram passagens com uma clara ênfase pedológica. Por exemplo, no trecho sobre as chapadas e os sedimentos Terciários, reconhecidos por Hartt em caráter pioneiro:

"Nas bacias do Jequitinhonha e Pardo, uma grande espessura de argilas mais ou menos arenosas, arenitos, e outros, foi depositada, enchendo os vales em alguns lugares, até alturas de 1000 pés, convertendo-os em imensa planície, cujo nível acima do mar deve exceder 3000 pés. Chamo tais depósitos de Terciários, porque ao longo da costa se encontram imperturbados, sem sinais de distúrbios Cretáceos, e porque o lençol de drift se estende sobre eles".

Ou sobre os sobre os Latossolos das Chapadas:

"Toda a região é coberta superficialmente com argila de drift, vermelha, e seixos, e esta camada tem vinte ou mais pés de profundidade. Não se vêm rochas sólidas, mas nas descidas para os vales, em certos barrancos, aflora a rocha, em estado muito decomposto, em camadas fortemente inclinadas".

\section{Observações do geólogo Theodoro Sampaio}

Tem-se ainda como testemunho deste mesmo período os trabalhos de Theodoro Sampaio(24) que discutem superficialmente sobre o solo, com ênfase nos substratos geológicos e raras menções ao manto superficial. Seguem-se algumas transcrições:
Sobre o semi-árido: "O granito aflora freqüentemente no meio da planície. Diques de uma rocha de base feldspática (pegmatitos), atravessam os caminhos e surgem a miúdo por entre as touceiras dos cardos. $O$ solo está coberto de seixos e fragmentos de quartzo branco ou corado de vermelho-ferrugem."

Sobre os solos salinos, marcados por carnaubais:

"Apareceram os bosques de carnaúbas assinalando quase sempre um solo salgado que os moradores exploram, lavando, coando e evaporando para apurarem o sal.”... “O solo da salina é ordinariamente um terreno argiloso, seco, de aluviação, com superfície mais ou menos plana onde aparecem manchas irregulares como as de um corpo graxo ou óleo derramado sobre a terra. São estas manchas de florescências salinas superficiais e pouco extensas que o povo costuma raspar, reunindo a terra para lançá-la em cochos de madeira onde fazem a decoada, que é depois evaporada ao sol no côncavo de grandes lajedos ou fervida ao fogo."

Sobre os solos aluviais do São Francisco:

“...com muitos brejos e alagadiços porque o terreno sendo sujeito às inundações do São Francisco oferece fraca e irregular inclinação ... O solo é todo aluvial."

Sobre o profundo mato de intemperismo sobre as rochas máficas:

"O solo em que predomina o barro vermelho é fértil... Sob o manto de argila mais ou menos espesso que a mata rigorosa encobre, dificilmente se percebe qual a natureza da rocha subjacente."

Ou sobre os vertissolos baianos, escorregadios:

"O solo negro e resvaladiço semelhante ao famoso massapé..."

Em síntese, observa-se que nesta fase de avanço de conhecimentos, no terreno edafológico pouco evoluiu, continuando o solo a ser tido como um prolongamento da rocha e referido genericamente como "terra fértil, infértil ou estéril. A preocupação destes cientistas era voltada, quase exclusivamente, à geologia e litologia, fonte dos recursos minerais de alto valor econômico que procuravam. De certo modo poder-se-ia até, considerar-se um retrocesso em relação ao período anterior, no qual até esboços de classificação foram tentados, ainda que de maneira bem empírica e grosseira, em que se davam nomes aos solos em função das características morfológicas mais evidentes.

\section{O SÉCULO XX E O NASCIMENTO DA PEDOLOGIA NO BRASIL}

Já na infância da Ciência de Solos brasileira, cientistas sociais com uma visão ecológica, como

(22) Sobre a suposta origem biológica do drift, ver revisão de Schaefer (1996) sobre o tema.

(23) No caso da Amazônia, os latossolos assentam-se sobre depósitos sedimentares terciários, correlatos ao Grupo Barreiras, ou supostamente mais antigos (Form. Alter do Chão).

(24) Theodoro Sampaio, engenheiro e geólogo brasileiro, subiu o curso do rio São Francisco entre 1879 e 1880 , desde a foz até Pirapora, para observação das condições de navegabilidade. Em continuação das sua explorações atravessou a "Chapada Diamantina" partindo de Carinhanha no Rio São Francisco até S. Félix próximo às nascentes do Rio Paraguassu. O relato da viagem está repleto de informações principalmente de natureza geográfica e geológica, algumas de grande profundidade. 
Gilberto Freyre (em seu admirável Nordeste, em 1937) já tratavam de deslindar as relações vitais solo-homemágua-vida, estabelecendo as bases da Ecologia Humana brasílica. Esta visão integradora, claramente reconhecida nos primeiros quartéis do século XX, passa a ser negligenciada nos últimos, pela ênfase, talvez excessiva, no aspecto econômico/agronômico do uso dos solos. Destacamos, para servir de modelo exemplar de cronistas da época, o relato pioneiro de Euclides da Cunha em 1905, designado "Um paraíso perdido: a expedição ao Alto Purus”:

"Em todas as latitudes foi sempre gravíssima nos seus primórdios a afinidade eletiva entre a terra e o homem;

... A Amazônia é, talvez, a terra mais nova do mundo. Nasceu de uma convulsão geogênica que sublevou os Andes, e mal ultimou o seu processo evolutivo com as várzeas quaternárias que se estão formando na topografia instável".

Para um fechamento adequado sobre as origens históricas da pedologia no Brasil, destacamos a participação de Marbut, ao relatar a viagem ao Vale do Amazonas (Geologia, Physiografia e Solos 1923). Nesta fase, como pode ser depreendido do texto, fica evidente o amadurecimento dos conceitos, alguns válidos e aplicados aos dias de hoje; o fato mostra, ainda, o rápido amadurecimento da pedologia norteamericana nos primeiros quartéis do século $\mathrm{XX}$, que anos mais tarde traduzir-se-ia em liderança na Ciência dos Solos à nível mundial, e no lançamento da "Soil Taxonomy", em 1975 :

\section{"Os solos de Aluvião do Amazonas}

Tomados no seu todo, como um grupo, estes solos são extremamente jovens no estágio de desenvolvimento. Na maioria dos casos, são perfis mais geológicos que pedológicos, em virtude da natureza sedimentar, e não pedogenética, após a deposição. Desde a sua deposição pelas inundações dos rios, praticamente não sofreram alterações em suas feições texturais. Ou adiante: Na bacia Central do Amazonas, a mudança mais notável havida nos solos de aluvião é a acumulação de uma leve camada de matéria orgânica de uma ou duas polegadas na superfície e maior ou menor desoxydação nos compostos de ferro do subsolo. A primeira mudança é muito leve mas não difere essencialmente, a esse respeito, dos solos das outras regiões florestais do mundo".

Ou ainda sobre a ação biológica nos solos tropicais:

"A fraca eluviação nos solos da Bacia Amazônica, onde as chuvas são fortes, pode ser creditada à fatores importantes, que condicionam o processo: são eles a cobertura vegetal densa e a visivel atividade universal dos cupins e outros insetos".

Um dos pais da pedologia norte americana foi, assim, um dos pioneiros na associação da gênese de Latossolos (sem eluviação evidente) e a ação biológica, com destaque para os cupins (Schaefer 1996).

Em 1935 era fundada a Seção de Solos do IAC, tendo sido convidado o Dr. Paul Vageler, alemão de nascimento, para dirigir as pesquisas, cujos objetivos eram, entre outros: "a tentativa de identificação das diferentes unidades de solos". Já os primeiros levantamentos de solos no Brasil, utilizando as notações de horizontes A, B e C, foram feitas em 1936, por Teodureto de Camargo e Paul Vageler. Em 1941, José Setzer publica as características de 22 tipos ou classes de solos do Estado de SP, mantendo nomes de uso corrente dos agricultores ("Massapê, Salmourão, Terra Roxa, etc.). Em 1947, com a criação da Comissão de Solos do Ministério da Agricultura ${ }^{(25)}$, tiveram início os levantamentos sistemáticos do território nacional. Hoje, pelo menos ao nível exploratório/esquemático, todo o território brasileiro se encontra mapeado. Em 1969, surgem os primeiros compêndios de pedologia com enfoque brasileiro.

\section{CONSIDERAÇÕES FINAIS}

A relativa pobreza da pré-pedologia brasileira é um fato bem evidenciado pelos textos levantados. Tal fato não é exclusivo do Brasil, mas se aplica à maior parte dos países, se não à sua totalidade. Para encontrar uma melhor explicação, deve dizer-se que uma atenção maior foi dedicada à história natural dos seres vivos, pois a história da terra era quase uma obsessão desde a antigüidade. Assim, não compreendiam ou atentavam ao solo, a delgada camada da crosta que constituía o suporte básico direto ou indireto de todas as formas de vida. Mesmo sábios reconhecidos, como Agassiz, dispendem horas de trabalho elaborando explicações sobre a litologia e gênese das paisagens e do drift, sem sequer observar as nuances dos estratos superficiais onde as plantas mergulham as suas raízes. Não se deve também esquecer que o nascimento da pedologia resultou das observações de Dokuchaev, motivadas por uma acentuada crise na produção agrícola da Rússia. O solo só passou a ser estudado, quando, enquanto recurso natural, deixou de corresponder à expectativa de produções de alimentos.

Em caráter tentativo, podemos ver a história da prépedologia brasileira em três fases distintas:

1. uma fase inicial, sintetizada pelas...boas terras, boas águas e clima ameno;

2. a segunda fase, já em pleno período de produção agrícola, principalmente do açúcar, em que embora empiricamente e segundo critérios de produtividade, os solos foram distinguidos não só pelo potencial, mas também por aspectos morfológicos simples e facilmente detectáveis;

(25) Desde então, a Comissão passou sucessivamente a denominar-se Divisão de Pedologia e Fertilidade dos Solos, Equipe de Pedologia e Fertilidade dos Solos, Divisão de Pesquisa Pedológica, Centro de Pesquisa Pedológica, Serviço Nacional de Levantamento e Conservação do Solo, e finalmente Centro Nacional de Pesquisa de Solos, da EMBRAPA, Rio de Janeiro. A Sociedade Brasileira de Ciência do Solo foi criada em 1947 (Moniz, 1997). 
3. a terceira fase, em que dado o número de cientistas envolvidos e nível de conhecimentos físicos, químicos, bióticos, já existentes, consideramos como a mais estéril. Nota-se um grave desprezo pelo manto superficial intemperizado, em favor de outros ramos do conhecimento biótico e/ou físicos. Areias, argila arenosa vermelha, terra estéril, terra fértil, terra fresca, pedregosa, etc, são as palavras de maior profundidade científica que os naturalistas desta fase dedicaram ao solo.

Como quarta fase, há o nascimento da pedologia brasileira em suas bases modernas, já no século vinte. O lento processo de evolução das Ciências da Terra casa-se, ainda que tardiamente, com as Ciências Agrícolas, dando os frutos conhecidos. Esta união, que sempre encontrou um sem-número de entraves e vicissitudes, ainda precisa evoluir muito, como ciência básica e aplicada, para responder às demandas de hoje e do futuro.

\section{REFERÊNCIAS BIBLIOGRÁFICAS}

AGASSIZ, L. 1869. A Journey in Brazil. Boston, Ticknor and Fields. $540 \mathrm{p}$.

ANTONIL, A.J. 1711. Cultura e Opulência do Brasil. São Paulo, Edição Melhoramento/MEC. 1976. 239 p. (ed. especial confrontada com a de 1711 acrescida de notas e comentários).

BATES, H. W. 1876. The naturalist on the river Amazons. John Murray edit. London. (ed. em português: 1944, São Paulo, Cia. Editora Nacional).

BURTON, R. 1869. Viagem de Canoa de Sabará ao Oceano Atlântico. São Paulo. Livraria Itatiaia Editora ,1977. 359 p. (Coleção Reconquista do Brasil. Vol. 37.).

BURTON, R. 1869. Viagem do Rio de Janeiro a Morro Velho. São Paulo, Livraria Itatiaia Editora, 1976. 366 p. (Coleção Reconquista do Brasil. Vol. 36).

CARNEIRO, R. 1961. Slash and burn agriculture: a closer look at its implications for settlement patterns. In: Men and cultures, A. F. C. Wallace (Ed.). Selected Papers of $5^{\text {th }}$ Int. Cong. Anthr. And Ethn. Sciences.

COOPER, M.; TERAMOTO, E. R.; TORRADO, P. V.; LEPSCH, I. F. \& GIANNINI, I. V. 1995. Classificação de Solos Utilizada pelos Índios Xicrin do Cateté (Carajás- PA). XXV Congresso Brasileiro de Ciência do Solo. Resumos Expandidos, vol. III, V- 018, p 1497. SBCS. UFV. Viçosa- MG.

COUTO, J.V. 1799. Memória sobre a Capitania das Minas Gerais: Seu Território Clima e Produção Metálicas. Belo Horizonte. Fundação João Pinheiro. Estudo de Júnia Ferreira Furtado. 1994. 104 p. (Coleção Mineiriana. Série Clássicos)

CUNHA, E. da. 1902. Os Sertões. Rio de Janeiro, Ediouro. 1995. 297 p. (17 . ed.)

CUNHA, E. da. 1905. Um Paraíso Perdido. Ensaios, Estudos e Pronunciamento sobre a Amazônia. José Olympio Editora. 1986. 27pp. (Coleção documentos brasileiros Vol. 203).

D' ORBIGNY, A. 1836. Viagem Pitoresca através do Brasil. São Paulo, Livraria Itatiaia Editora , 1976. 190 p. (Coleção Reconquista do Brasil. Vol. 2 ).

DEBRET, J.B.; Viagem Pitoresca e Histórica ao Brasil. Vol. I. Círculo do Livro, São Paulo. 348 p.

ESCHWEGE, W.L. von. 1833. Pluto Brasiliensis. In: Collectanea de Scientistas Estrangeiros (Assuntos Mineiros). Vol. I. Belo Horizonte, Imprensa Oficial do Estado de Minas Gerais. 1922. pp 153-526.

FERREIRA, A.R. 1783. Diário da Viagem Philosophica pela Capitania de São José do Rio Negro com a Informação do Estado Presente. In: Revista Trimestral do Instituto Histórico, Geographico e Etnographico do Brasil Tomo XLVIII, Parte 1, p. 1 - 234 - 1.a parte 1885 . Tomo XLIX, 1 volume p. 123 - 288, 2.o vol. 11-141 - 2a Parte. 1886.
GUMILLA, J. 1791. Historia natural, civil y geografica de las naciones situadas en las riveras del rio Orinoco. 2 vols. Barcelona. (Publ. Originalmente como: Orinoco Ilustrado..., Madrid, 1741).

HARTT, C.F. 1879. Geologia e Geografia Física do Brasil. São Paulo, Companhia Editora Nacional. 1941. 649 p.

HYAMS, E. 1952. Soil and Civilization. London, Thames and Hudson. $312 \mathrm{p}$

LERY, J. de. 1578. Viagem à Terra do Brasil. Rio de Janeiro. Biblioteca do Exército Editora. 1961. 279pp.

MARBUT, C.F. 1923. Geologia, Physiographia e Solos (Valle do Amazonas). Separata da Parte II do Relatório da Comissão Brasileira junto à Missão Official Norte-Americana de estudos de Valle do Amazonas. Serviço Geológico e Mineralógico do Brasil.pp 341-416.

MARBUT, C.F. 1938. A scheme of soil classification. In: Internat. Cong. Soil Science, 1. Washington, Proceeding... 1938, 4:131 .

MAWE, J. 1810. Viagem ao interior do Brasil. Particularmente aos distrito do Ouro e do Diamente, em 1809-1810. (trad. de D. Lessa). Belo Horizonte, Imprensa Oficial do Estado de M.G. 1922.

MONIZ, A. C. 1997. História da Pedologia no Brasil. Boletim da Revista Brasileira de Ciência do Solo. pp. 9.

MORAES, L.J. de.1924. Serras e Montanhas do Nordeste. Rio de Janeiro. Inspectoria Federal de Obras Contra as Secas. Vol. I, 122 p. Vol. II 120 p. (Publ. 58 Série ID.).

PAES LEME, A.B. 1924. Evolução da Estrutura da Terra e Geologia do Brasil. Rio de Janeiro. Imprensa Nacional. 368 p.

POHL, J.E. 1832. Viagem no Interior do Brasil. São Paulo. Livraria Itatiaia Editora Ltda, 1976. 417 p. (Coleção Reconquista do Brasil, Vol. 14).

SAINT-HILAIRE, A. de. 1830. Viagem pelo Distrito dos Diamantes e Litoral do Brasil. São Paulo, Livraria Itatiaia Editora. 1974. 233 p. (Coleção Reconquista do Brasil, Vol. 5).

SAMPAIO, T. O 1879. Rio de São Francisco, e trecho de um Diário de Viagem a Chapada Diamantina (1879-80). São Paulo. Escolas Profissionais Salesianas,. 1905. 195p.

SCHAEFER, C. E. R. \& EDEN, M. 1995. Os Solos e os Povos Indígenas de Roraima: Um ensaio de Ecologia Humana. XXV Congresso Brasileiro de Ciência do Solo. Resumos Expandidos, vol. III, V- 017, p 1494. SBCS. UFV. Viçosa- MG.

SETZER, J. 1949. Os Solos do Estado de São Paulo. Rio de Janeiro. Instituto Brasileiro de Geografia e Estatística, 387p. (Série A).

SPIX, J. B. von \& MARTIUS, C. F. P. von. 1823. Viagem pelo Brasil. (1817-1820). Trad. de Lúcia Furquim Lahmeyer. Instituto Histórico e Geográfico Brasileiro, 3aㅗ ed., São Paulo, Melhoramentos: Brasília, INL, 1976. 3v. ilust. 231p.

SPIX, J. B. von; MARTIUS, K. F. P. von. (1823). Reise in Brazilien auf Befehl. (1831) S. M. Konig Maximilian Joseph I von Bayern. Munique.

STEINEN, K. von den. 1894. Unter den Naturvõlkern ZentralBrasiliens. Berlim (2 $2^{-}$ed. 1897; em português: São Paulo, 1940).

THEVET, A. 1558. Les singularités de la France antartique, autrement nommée. Amérique: et Isles découvertes de notre temps. (Ed. Anotada por Paul Gaffarel. Paris. (Paris ed., 1557; Anvers ed. 1558). (Ed. em português: São Paulo, 1944)).

TSCHUDI, J.J. von. Viagem às províncias do Rio de Janeiro e São Paulo. Belo Horizonte, Editora Itatiaia/Universidade de São Paulo. 1980. 218p. (Coleção Reconquista do Brasil, vol 14).

VASCONCELOS, D.P.R. de. Breve Descrição Geográfica, Física e Política da Capitania de Minas Gerais em 1807. Estudo Crítico de Carla Maria Anastásia. Belo Horizonte, Fundação João Pinheiro. 1994. 188 p. ( Coleção Mineiriana - Série Clássicos).

VIEIRA, L.S.; CARVALHO E OLIVEIRA, N. V. de; BASTOS, T. $\mathrm{X}$. Os Solos do Estado do Pará. Belém. Instituto do Desenvolvimento- Econômico Social do Pará, 1971. 175p. (Cadernos Paraenses, 8).

WALLACE, A. R. (1853). A narrative of travels on the Amazon and Rio Negro. Londres; New York. (Outra ed.: New York, Melbourne, Londres, 1870,1889. Edit. em português: São Paulo, 1939). 